\title{
TÉCNICAS DE ATENDIMENTO PARA CONVERTER LEADS EM VENDAS NO ATUAL CENÁRIO ECONÔMICO
}

\section{ARTIGO ORIGINAL}

REFFATTI, Guilherme Vanni ${ }^{1}$

QUIRICI, Wagner ${ }^{2}$

REFFATTI, Guilherme Vanni. QUIRICI, Wagner. Técnicas de atendimento para converter leads em vendas no atual cenário econômico. Revista Científica Multidisciplinar Núcleo do Conhecimento. Ano 05, Ed. 12, Vol. 16, pp. 103-108. Dezembro de 2020. ISSN: 2448-0959, Link de acesso: https://www.nucleodoconhecimento.com.br/administracao/converter-leads

\section{RESUMO}

Assim como quase todos os setores da Economia brasileira, o ramo imobiliário mudou muito desde a crise do início de 2014. Com cada vez menos clientes dispostos a comprar imóveis, a conversão de leads em vendas tornou-se essencial para o desenvolvimento desse importante segmento da Economia. $\mathrm{O}$ presente artigo traz a

\footnotetext{
${ }^{1}$ Mestrando pela Universidade de Caxias do Sul (UCS), MBA em Gestão Comercial pela Faculdade da Serra Gaúcha (FSG), MBA em Gestão de Negócios Imobiliários pela Faculdade de Desenvolvimento do Rio Grande do Sul (FADERGS), MBA em Gestão de Empresas pela Universidade Brasileira de Formação (UniBF). Pósgraduação em Docência no Ensino Técnico e Superior pela Faculdade Qi (FAQi), Bacharel em Ciências Econômicas pela Universidade de Caxias do Sul (UCS), estudante do 4ำ Semestre de Licenciatura em Matemática pela Faculdade das Américas (FAM), Técnico em Transações Imobiliárias pelo Instituto Brasileiro de Formação (IBREP) e Perito avaliador de imóveis também pelo IBREP.

2 Orientador. Mestre em Administração. Graduação em Engenharia Eletrônica.
} 
opinião e os ensinamentos dos maiores corretores de imóveis do Brasil, formas de driblar a crise e a melhor e mais eficiente forma de converter leads em vendas efetivas.

Palavras-chaves: Leads, vendas, marcado imobiliário, cenário econômico.

\section{INTRODUÇÃO}

A economia brasileira viveu um período muito próspero até 2013, com uma economia extremamente acelerada e uma expansão jamais vista no segmento imobiliário do país. Os corretores de imóveis se acostumaram a vender muito e de forma muito facilitada. A Caixa Econômica Federal e os demais bancos de varejo disponibilizavam muito crédito, com taxas atrativas e com pouca burocracia. Nessa época os leads eram quase descartáveis dados a sua abundância.

Atualmente a situação mudou. A crise financeira que perdura desde 2014 reduziu muito a atividade econômica e afetou em cheio o mercado imobiliário. Nessa nova realidade, poucos leads, ou seja, pessoa interessada em possuir e/ou adquirir um produto ou serviço, chegam até os corretores de imóveis e devem ser valorizados ao extremo a fim de serem convertidos em vendas.

Os corretores de imóveis precisaram de muita especialização, aprender mais sobre a área financeira, marketing, comportamento do consumidor e principalmente aprimorar $o$ atendimento e o tratamento dado aos poucos leads que aparecem nos estandes de vendas.

\section{CONVERTENDO LEADS EM VENDAS: TÉCNICAS DE ATENDIMENTO PRINCIPAIS}

Acostumados a uma fase onde se atendiam muitos leads e os negócios apareciam muito facilmente, hoje os corretores de imóveis se deparam com um período de pouca ou nenhuma demanda. Raros clientes entram no estande de vendas de sua imobiliária, poucos clientes ligam no plantão ou mesmo entram em contato via internet. Aquele lead que ainda procura imóvel deve obrigatoriamente ser convertido em venda. 
Fundamentado nas obras dos especialistas do ramo imobiliário Guilherme Machado e Paulo Angelim e nos famosos escritores Dale Carnegie e Idalberto Chiavenato podem-se: identificar, aprimorar, melhor atender e converter esses leads em vendas com extrema acuracidade e eficiência.

Dentro da caracterização e expectativas dos clientes, Chiavenato (2006, p. 61) menciona que é importante comparar "[...] as expectativas ao seu redor com os resultados que você está oferecendo. Esse diferencial entre o que esperam de você e o que você está entregando precisa ser corrigido". O autor coloca de forma muito adequada um grande problema da atividade imobiliária, a satisfação plena do cliente. Essa atitude deve ser revista e deve-se esquecer da antiga prática de empurrar ao cliente o que os corretores de imóveis, as imobiliárias, incorporadoras e construtoras querem vender. A necessidade do cliente geralmente é diferente da necessidade do agente imobiliário e deve ser respeitada plenamente.

Caracterizado o cliente o segundo passo que o profissional da área imobiliária deve seguir é a preparação mental. Paulo Angelim, em sua obra Seja você o campeão de vendas, comenta:

Se você deseja realmente ser um corretor campeão, o primeiro grande desafio a que você deve se submeter, antes de iniciar sua preparação, é o da mudança de atitude mental. Você deve, desde já, criar uma disposição mental de aprendizado. A preparação do corretor nada mais é que um processo contínuo e ininterrupto de aprendizado. (ANGELIM, 2004, p. 13).

Trabalhar da mesma maneira e esperar resultados diferentes não parecem ser atitudes muito inteligentes, porém é o que a maioria faz. Aprendizado contínuo e aperfeiçoamento tornam-se necessidades vitais para o desenvolvimento do profissional da área imobiliária e as únicas alternativas para a saída do marasmo dos resultados negativos ou pouco expressivos.

Dentro da esfera da excelência em atendimento o famoso autor Dale Carnegie proferiu as seguintes sábias palavras: 
Se quiser que as pessoas gostem, se quiser aprofundar verdadeiras amizades, se quiser ajudar as outras pessoas e ao mesmo tempo ser ajudado por elas, procure lembrar-se deste princípio: Torne-se verdadeiramente interessado na outra pessoa. (CARNEGIE, 2012, p. 98).

Necessita-se questionar e ouvir o cliente com muita atenção, muito mais do que preocupar-se em falar, vender ou apresentar o produto. O lead está claramente procurando algum produto ou serviço e necessita falar, explicar e até certo ponto se abrir para o profissional que o atende. Aprendendo a ouvir com atenção pode-se dar a cartada certeira, oferecer o produto adequado e converter o atendimento em vendas e novos negócios imobiliários.

Deve-se também entender que cada cliente é diferente e busca produtos e serviços diferentes. Sendo assim não se pode de forma alguma ter uma regra e padrão préestabelecidos de atendimento. O fato de ouvir e bolar estratégias mentais de atendimento, aliado a um encaixe entre o lead e o corretor de imóveis deve gerar possibilidades maiores de fechamento de negócios. O graduado corretor de imóveis e palestrante Guilherme Machado fala o seguinte sobre o assunto:

Se você entender que consegue vender mais quando sai do piloto automático e compreende o cliente com mais facilidade, certamente irá se empenhar para construir esse novo hábito. Pense nisso, em vez de ficar achando que seus clientes são loucos, pois eles o procuram, mas depois não voltam nunca mais. Liberte-se de conceitos preestabelecidos. Foque na demanda do seu cliente, satisfaça as necessidades dele e venda. (MACHADO, 2017, p. 128).

O cliente bem atendido, bem ouvido, que se sinta valorizado torna-se fiel ao corretor de imóveis e deixa de procurar imóveis com os concorrentes, aguardando as opções que esse tem a oferecer e tratando a relação de consumo como uma relação da amizade e de troca mútua. Mudança de atitude é tudo.

\section{CONCLUSÃO}

Uma correta identificação de quem é cliente e quem é um mero curioso especulando, sem perdas de energia e de tempo. Tratar o lead com cortesia e muita eficiência, 
despertando empatia e confiança. Atender o futuro cliente com pró-atividade, estando psicologicamente preparado para os desafios que serão impostos. Finalmente, converter esse lead em novos negócios, novas indicações e principalmente em venda e muita rentabilidade. Assim deve ser o roteiro do corretor de imóveis brasileiro moderno na era pós-crise.

Pode-se e devem-se adotar as técnicas dos autores mencionados, com teorias testadas e aprovadas, pendendo para uma excelência no atendimento e uma gestão profissional dos clientes. Essa é a única solução para que se possa sobreviver a essa duradoura crise e possa-se continuar prosperando nessa economia instável e de lenta ou nenhuma recuperação, superando a falta de crédito e de confiabilidade do mercado.

\section{REFERÊNCIAS BIBLIOGRÁFICAS}

ANGELIM, P. Seja você o campeão em vendas: como vender mais imóveis em menos tempo. São Paulo: Mundo Cristão, 2004.

CARNEGIE, D. Como fazer amigos e influenciar pessoas. 52. ed. São Paulo: Companhia Editora Nacional, 2012.

CHIAVENATO, I. Cartas a um jovem administrador: o futuro está na administração. Rio de Janeiro: Elsevier, 2006.

MACHADO, G. Você não vai mais conseguir vender assim: quebre as regras e torne-se um profissional de alto impacto: reconstrua o que você sabe sobre vender. São Paulo: Gente, 2017.

Enviado: Julho, 2020.

Aprovado: Dezembro, 2020. 